\title{
Tenascin-C Splice Variant Adhesive/anti-Adhesive Effects on Chondrosarcoma Cell Attachment to Fibronectin
}

\author{
Michelle A. Ghert ${ }^{1}$, Wen-ning Qi ${ }^{1}$, Harold P. Erickson², Joel A. Block ${ }^{3}$, and Sean P. Scully ${ }^{*}$ \\ ${ }^{1}$ Division of Orthopaedic Surgery, Duke University Medical Center, Durham, NC, ${ }^{2}$ Department of Cell Biolo- \\ gy, Duke University Medical Center, Durham, NC, ${ }^{3}$ Department of Rheumatology, Rush-Presbyterian St. Luke's \\ Medical Center, Chicago, IL, and ${ }^{4}$ Department of Orthopaedic Surgery, Mayo Clinic, Rochester, MN
}

\begin{abstract}
Tenascin-C is an oligomeric glycoprotein of the extracellular matrix that has been found to have both adhesive and anti-adhesive properties for cells. Recent elucidation of the two major TNC splice variants (320 kDa and $220 \mathrm{kDa}$ ) has shed light on the possibility of varying functions of the molecule based on its splicing pattern. Tenascin- $\mathrm{C}$ is prominently expressed in embryogenesis and in pathologic conditions such as tumorogenesis and wound healing. Fibronectin is a prominent adhesive molecule of the extracellular matrix that is often co-localized with tenascin- $\mathrm{C}$ in these processes.

We studied the chondrosarcoma cell line JJ012 with enzyme-linked immunoabsorbance assays, cell attachment assays and antibody-blocking assays to determine the adhesive/anti-adhesive properties of the two major tenascin$\mathrm{C}$ splice variants with respect to fibronectin and their effect on chondrosarcoma cell attachment. We found that the small tenascin-C splice variant $(220 \mathrm{kDa})$ binds to fibronectin, whereas the large tenascin-C splice variant (320 kDa) does not. In addition, the small tenascin-C splice variant was found to decrease adhesion for cells when bound to fibronectin, but contributed to adhesion when bound to plastic in fibronectin-coated wells. Antibody blocking experiments confirmed that both the small tenascin- $\mathrm{C}$ splice variant and fibronectin contribute to cell adhesion when bound to plastic. The large tenascin-C splice variant did not promote specific cell attachment. We hypothesize that the biologic activity of tenascin- $\mathrm{C}$ is dependent on the tissue-specific splicing pattern. The smaller tenascin-C isoform likely plays a structural and adhesive role, whereas the larger isoform, preferentially expressed in malignant tissue, likely plays a role in cell egress and metastasis.
\end{abstract}

Key words: tenascin-C/splice variant/chondrosarcoma/cell/adhesion/fibronectin

Tenascin-C (TNC) is an oligomeric glycoprotein of the extracellular matrix (ECM) that has been found to be expressed in a variety of processes including cartilage development (Gluhak et al., 1996; Mackie and Murphy, 1998; Mackie and Ramsey, 1996; Pacifici, 1995), tissue remodeling, wound healing (Dalkowski et al., 1999; Hakkinen et al., 2000; Jones et al., 2000; Latijnhouwers et al., 1996), angiogenesis (Gassler et al., 1999; Jallo et al., 1997; Klein-Soyer et al., 1997; Kostianovsky et al., 1997; Nicolo et al., 2000; Ribatti; 1998) and tumorogenesis (Kalembey et al., 1997; Kurpad et al., 1995; Riedl et al., 1997; Vacca et al., 1996; Wilson et al., 1999). TNC has also been implicat-

\footnotetext{
* To whom correspondence should be addressed: Department of Orthopaedic Surgery, Mayo Clinic, 200 First Street SW, Rochester, MN 55905.

Tel: +507-284-3797, Fax: +507-284-5075

E-mail: scully.sean@mayo.edu

Abbreviations: TNC, tenascin-C; ECM, extracellular matrix; FN, fibronectin.
}

ed in a variety of cell functions including cell adhesion and anti-adhesion, migration and metastasis (Vollmer, 1997). Fibronectin (FN) is another glycoprotein of the ECM that has a more widespread distribution than, but is often co-localized with TNC. Whereas FN is considered an adhesive substrate for cells (Goussia et al., 2000), TNC has been found in some laboratories to prevent cell adhesion to $\mathrm{FN}$ (Chiquet-Ehrisman et al., 1988).

Various domains of the TNC molecule have been associated with the adhesive or anti-adhesive properties of the molecule (Angelov et al., 1998; Aukhil et al., 1993; Chung et al., 1996; Elefteriou et al., 1999; Fischer et al., 1997; Fischer et al., 1997; Husmann et al., 1995; Kafitz and Greer., 1998; Kiernan et al., 1996). The molecular structure of TNC is that of a hexabrachion consisting of six subunit 'arms'. Each arm contains a variable splicing region that contains multiple fibronectin type III (FN-III) repeats (Fig. 1). Alter- 
native mRNA splicing creates two major TNC size variants that are identified as 220 and $320 \mathrm{kDa}$ bands on Western blot analysis (Erickson and Bourdon, 1989). In addition, 22 human splice variants have been identified with PCR analysis (Ljubimov et al., 1998). Recent elucidation of the TNC splice variants has shed light on the possibility of multiple functions of the molecule based on the splicing pattern, thus explaining the observation of both adhesive and antiadhesive properties. (Fischer, et al., 1997)

TNC is expressed in high concentrations in various malignancies including chondrosarcoma, a malignant cartilage-forming tumor (Kalembey et al., 1997; Kurpad et al., 1995; Riedl et al., 1997; Vacca et al., 1996; Wilson et al., 1999). However, TNC is also a major constituent of normal adult articular cartilage (Savarese et al., 1996) and premature cartilage (Pacifici, 1995), suggesting tissue specific function. Preliminary studies in our laboratory have shown a distinctly different in vitro TNC splicing pattern between cultured human chondrocytes and chondrosarcoma cells ((Ghert et al., 2000), submitted for review). The small $220-\mathrm{kDa}$ TNC isoform is the predominant splice variant expressed and produced by the chondrocytes and is incorporated into the matrix. In contrast, the malignant cells express and produce predominantly the large $320-\mathrm{kDa}$ TNC splice variant that exhibits almost no matrix incorporation.

The different roles played by the two major TNC splice variants in human articular cartilage and chondrosarcoma cells may be a function of the adhesive/anti-adhesive properties of each splice variant. Elements of the metastatic cascade include cell detachment from the matrix and cell egress, both requiring anti-adhesive matrix components. We have used enzyme-linked immunoabsorbance assays, cell attachment assays and antibody blocking assays to determine the specific adhesive/anti-adhesive properties of the two major TNC splice variants with respect to chondro- sarcoma cell attachment to FN. We hypothesize a possible role for the specific TNC splicing pattern in the metastatic behavior of the chondrosarcoma cells.

\section{Materials and Methods}

\section{Enzyme-linked immunoabsorbance assay}

Purified human FN (Chondrex, Seattle, WA, USA) was diluted in phosphate buffer saline (PBS) to a concentration of $2 \mu \mathrm{g} / \mathrm{ml}$. Human TNC large and small expression proteins (HxB.L and HxB.S) corresponding to the $320 \mathrm{kDa}$ and $220 \mathrm{kDa}$ proteins were diluted to a concentration of $10 \mu \mathrm{g} / \mathrm{ml}$. Human TNC was purified from conditioned medium of U-251MG human glioma cells by gel filtration and Mono Q chromatography (Aukhil et al., 1990; 1993) (H.Erickson, Duke Universtiy, Durham, NC, U.S.A.). The chosen concentrations (TNC five times less adhesive than FN) were based on pilot cell adhesion assays to determine the optimal cell binding concentration for each matrix protein (data not shown). Ninetysix-well immunoadhesive plates (Maxi Sorp; Nunc, Denmark) were coated overnight at $4^{\circ} \mathrm{C}$ with $50 \mathrm{ml}$ of the test protein (TNC or FN for single-protein wells and FN for double-protein wells). All wells were then rinsed with PBS.

In experiment $\mathrm{A}$, the wells were blocked for 1 hour at $37^{\circ} \mathrm{C}$ with $1 \%$ bovine serum albumin (BSA, Sigma Chemical, St. Louis, MO, USA) following FN adsorption and prior to the second protein coat (Fig. 2). In this manner, the plastic spaces left open by the FN coat were blocked by the BSA and nonspecific plastic binding sites were not available for the second protein coat. In experiment $B$, the second protein coat (TNC large or small protein) was added overnight at $4{ }^{\circ} \mathrm{C}$ prior to BSA blocking (Fig. 3). Therefore, in experiment A the TNC could bind only to the FN and not to the plastic, and in experiment $\mathrm{B}$ the TNC either could bind to the FN in or to the plastic exposed in the pores in between FN molecules. Negative control wells consisted of BSA coating only and were used to

\section{TNC:}

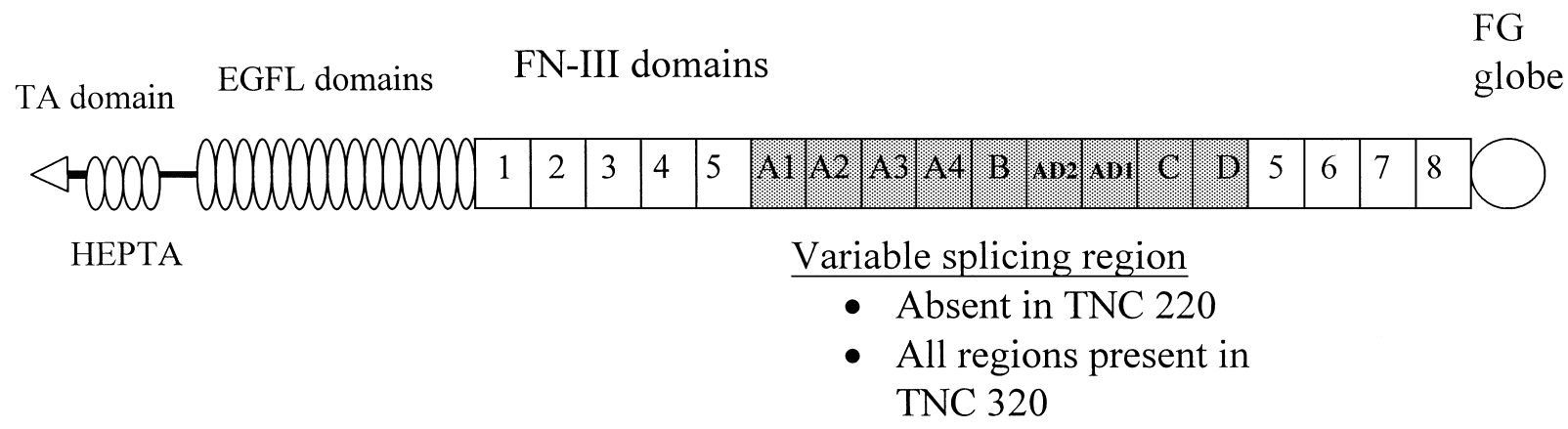

Fig. 1. Schematic diagram of the TNC hexabrachion arm. The tenascin assembly (TA) links six TNC chains via the heptad repeats. Proceeding in a carboxyl terminal direction, the domains are as follows: an array of 14.5 epidermal growth factor like repeats (EGFL), two types of FN-III domains: (1) those conserved in all variants of TNC (white boxes), and (2) those that are alternatively spliced (gray boxes), and the terminal fibrinogen knob (FG globe). In TNC 320, all alternatively spliced segments are present and in TNC 220, none of the alternatively spliced segments are present. 


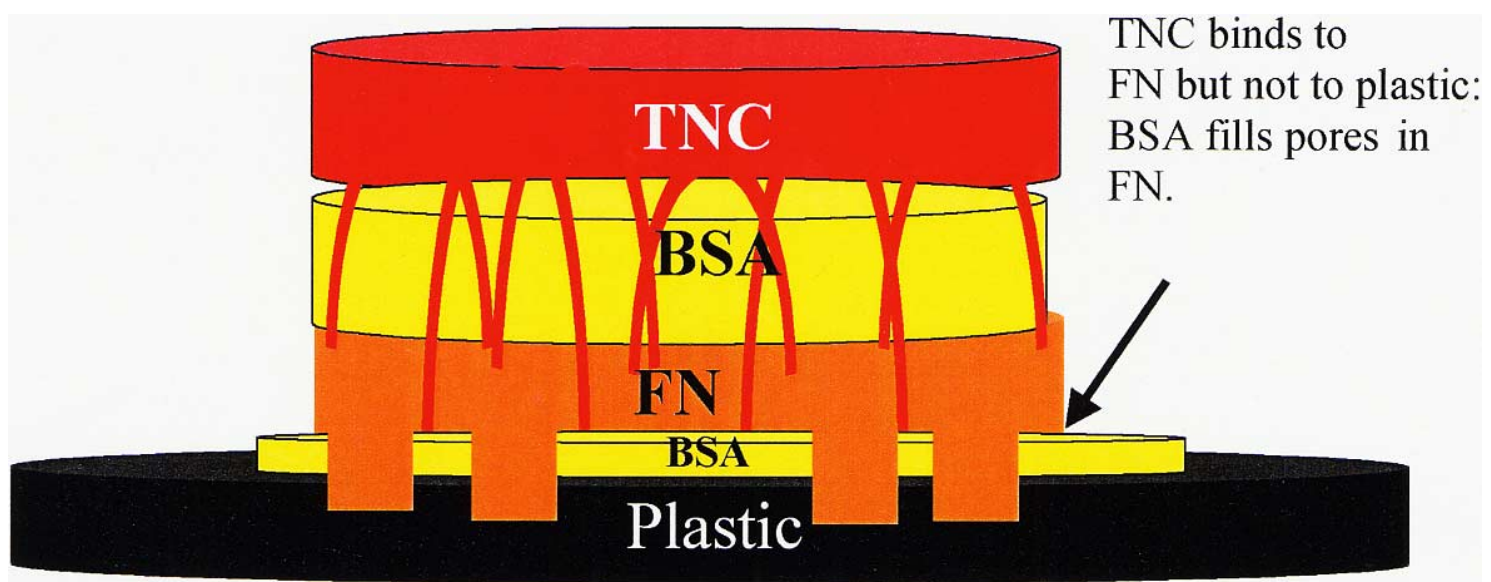

Fig. 2. Schematic diagram of experiment A in which the BSA is used in between protein coats to block nonspecific binding sites in the plastic that are exposed by pores in the FN layer. The TNC that is then incubated in the wells can bind only to FN and not the plastic. This experiment therefore specifically examines the binding properties of the two TNC splice variants to FN.

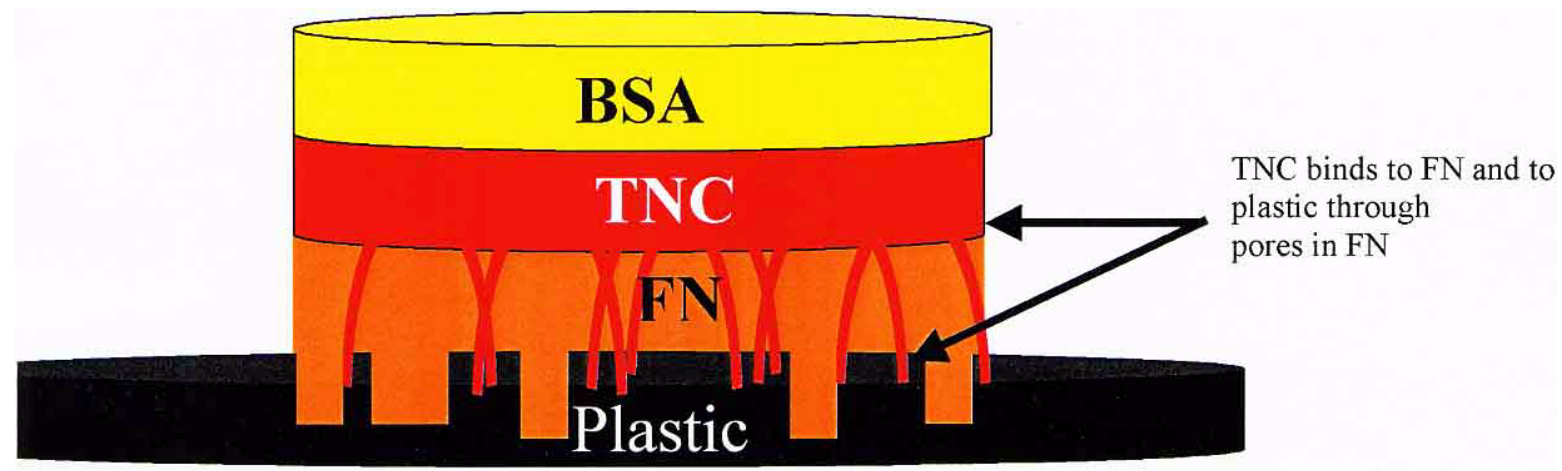

Fig. 3. Schematic diagram of experiment B in which the BSA is used after both protein coats. The TNC that is then incubated in the wells can bind specifically to FN and nonspecifically to the plastic.

subtract background adhesion.

The wells were rinsed with PBS and incubated for 2 hours at $37^{\circ} \mathrm{C}$ in a $1 / 2000$ dilution of the rabbit polyclonal anti-TNC antibody HxB.9504 (produced against FN-III domains 6-8 and the Cterminal knob, which is identical for both TNC splice variants, see Figure 1) (H.Erickson, Duke Universtiy, Durham, NC, U.S.A.) (Spring et al., 1989). The wells were rinsed with PBS-Tween (PBS-T) and incubated for 1 hour at $37^{\circ} \mathrm{C}$ with a secondary antirabbit $\operatorname{IgG}$ horseradish peroxide conjugated antibody (ECL, Amersham Pharmacia, Biotech, England). A peroxide-reactive color developing system and absorbance at $490 \mathrm{~nm}$ was used to quantitate the amount of protein bound.

\section{Cell adhesion assay}

Ninety-six-well immunoplates (Maxi Sorp; Nunc Denmark) were prepared as above for the ELISA protocol. The chondrosarcoma cell line, JJ012, was provided by Dr. Joel Block (J. Block, RushPresbyterian St. Luke's Medical Center, Chicago, IL, U.S.A.). The cells were cultured in a monolayer in basal media supplemented with $10 \%$ fetal bovine serum (FBS), split and re-plated at half-confluence two days prior to the assay. The cells were released from the substratum with $1 \mathrm{mg} / \mathrm{ml}$ trypsin, washed several times in $0.5 \%$ soybean trypsin inhibitor (Sigma Chemical, St. Louis, MO) and diluted in media to a concentration of $1 \times 10^{6} \mathrm{cells} / \mathrm{ml}$. At total of $1 \times 10^{5}$ cells $(100 \mu \mathrm{l})$ were added to each well and incubated for 1 hour at $37^{\circ} \mathrm{C}$. The wells were rinsed with PBS and a hexosaminidase substrate was added to the wells and incubated for 3 hours at $37^{\circ} \mathrm{C}$. The cell binding was quantitated by measuring endogenous hexosaminidase as previously described (Landegren, 1984).

\section{Antibody-blocking cell adhesion assay}

The cells adhesion assays were performed as described above. However, prior to the addition of the $J J$ cells to the prepared plates, all wells were incubated for 2 hours at $37^{\circ} \mathrm{C}$ in $100 \mu \mathrm{l}$ of one of three antibody blocking solutions. These solutions were: (1) a 1/500 solution of an antibody directed against the C-terminus of TNC (HxB.9504) (2) a 1/50 dilution of a mouse monoclonal antibody to the cell-binding site of FN (HB5) (H.Erickson, Duke 
Universtiy, Durham, NC, U.S.A.). (Spring, 1989), or (3) a 1:1 combined solution of TNC (HxB.9504) and FN (HB5) antibodies at the above dilutions. Following the antibody-blocking step, the wells were rinsed twice with T-PBS and twice with PBS to eliminate unbound antibodies. The $J J$ cells were then added to the wells as described above and attachment assays were performed.

\section{Data analysis}

All experiments were performed in triplicate. Data analysis was performed using t-test comparison of means (Microsoft Excel). A $\mathrm{P}$-value of less than 0.05 was considered statistically significant.

\section{Results}

\section{Enzyme-linked immunoabsorbence assay}

In experiment $\mathrm{A}$ in which $\mathrm{BSA}$ in between protein coats prevented nonspecific TNC binding to plastic, the small 220 $\mathrm{kDa}$ TNC splice variant bound to FN to a significantly greater extent than did the $320 \mathrm{kDa}$ TNC splice variant $(\mathrm{P}<0.001)$ (Fig. 4). The large TNC splice variant had negligible binding to FN. In contrast, in experiment B in which the BSA was added after both protein coats and nonspecific TNC binding to plastic was possible, both the small and large TNC splice variants bound to the FN-coated wells (Fig. 4). Of note, ELISA detection of FN in this experiment showed that the FN concentration did not decrease with the second protein coat nor between experiments A and B (data not shown). These results indicate that the small TNC isoform binds to FN and that the large TNC isoform does not. However, if plastic sites are available for nonspecific binding in the FN-coated wells, the large TNC splice variant will bind in the wells.

\section{Cell attachment assay}

In experiment $\mathrm{A}, J J$ cell attachment to $\mathrm{FN}$ was unaffected in the wells where the large TNC $320 \mathrm{kDa}$ protein was added as a second coat $(\mathrm{P}=0.15)$ (Fig. 5). This negative result is consistent with the absence of binding of TNC 320 in this protocol. In contrast, cell binding to $\mathrm{FN}$ was significantly inhibited in the wells where the small $220-\mathrm{kDa}$ protein was bound to $\mathrm{FN}(\mathrm{P}<0.01)$. These results indicate that the specific binding of the small TNC isoform to $\mathrm{FN}$ inhibits chondrosarcoma attachment to $\mathrm{FN}$ in vitro. In contrast, in experiment B where BSA was added after both coats, the attachment of the small TNC protein to the available plastic sites significantly increased $J J$ cell adhesion to the FN-coated wells $(\mathrm{P}<0.05)$ (Fig. 5). The mechanism through which this increased adhesion occurs was not further explored in this study. The attachment of the large TNC protein to the plastic sites did not affect $J J$ cell adhesion to the FN-coated substrate $(\mathrm{P}=0.15)$. This suggests that the small 220-kDa TNC splice variant has adhesive properties for chondrosarcoma cells if the protein is allowed first to bind

\section{Experiment A: BSA in between protein coats}

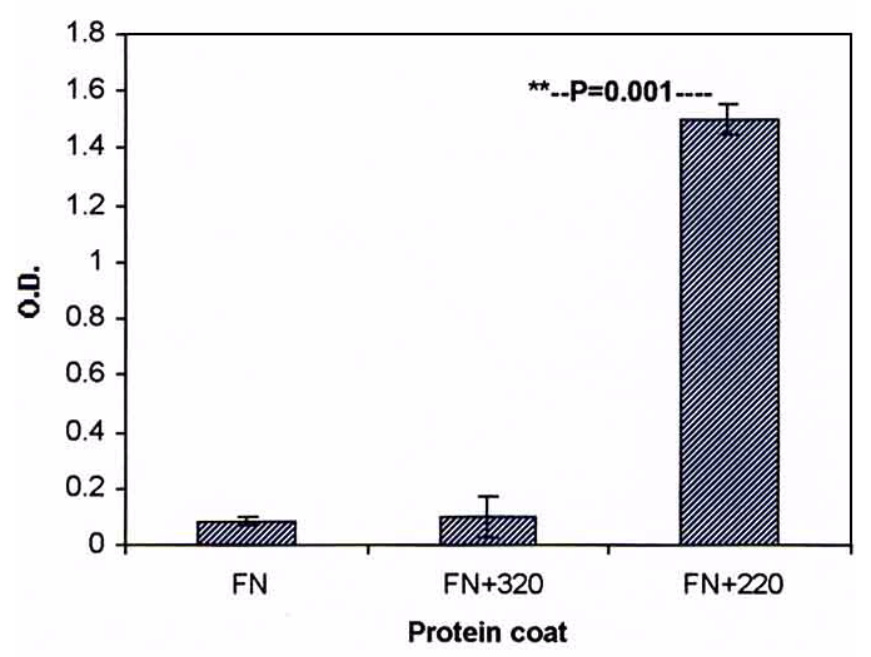

\section{Experiment B: BSA after both protein coats}

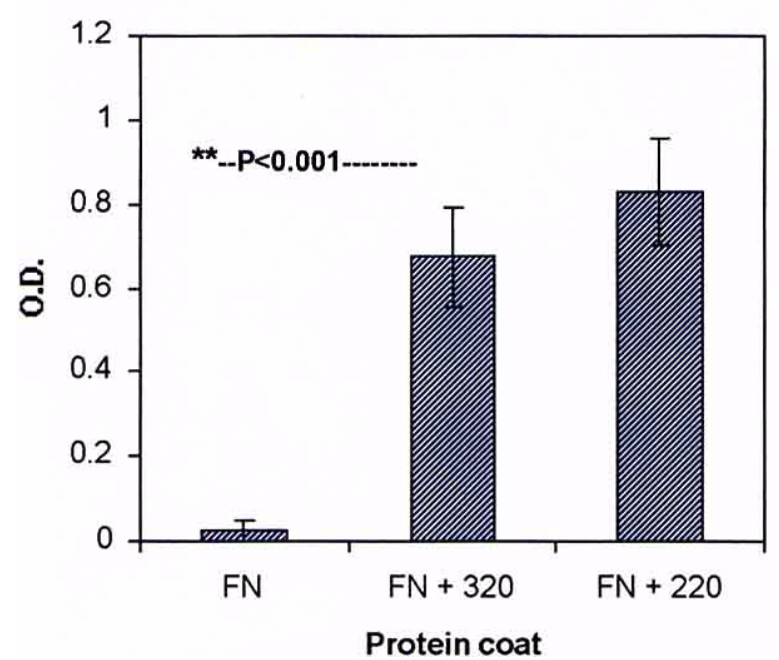

Fig. 4. Quantitation of bound substrate in enzyme-linked immunoabsorbance assay with the polyclonal antibody HxB.9504 (anti-TNC terminal knob, identical for all TNC). All experiments were performed in triplicate. The error bars represent standard deviation and statistical analysis was performed with the use of the student's t-test analysis of variance. A Pvalue of $<0.05$ was considered statistically significant. In experiment A (top) in which nonspecific binding sites were blocked after coating with FN, significantly more of the small TNC splice variant bound to FN than did the large TNC splice variant $(* * \mathrm{P}=0.001)$. The large $\mathrm{TNC}$ isoform had negligible binding in the wells. In experiment $\mathrm{B}$ (bottom) in which the TNC protein layer was exposed to both FN and plastic binding sites, both the large and small TNC splice variants were found to bind in the wells. In contrast to experiment A, the large splice variant had significant binding in the wells $(* * \mathrm{P}<0.001)$. 
to plastic. If the small TNC isoform is bound to FN, the double-protein complex has anti-adhesive properties (Fig. 5).

\section{Antibody blocking attachment assays}

As displayed in Figure 6, experiment A, the blocking of the TNC with the polyclonal antibody HxB.9504 was performed after both protein coats (BSA in between coats). This was examined for TNC 220 and FN combinations only, as TNC 320 was found in the cell adhesion assays above not to have any significant effect on cell adhesion. In all wells, the antibody did not significantly affect $J J$ cell attachment. Of note, the results of cell attachment assay A were confirmed: the TNC220:FN complex significantly inhibited $J J$ cell attachment $(\mathrm{P}<0.05)$. We hypothesize that the reason that the anti-TNC antibody did not affect cell adhesion in the TNC220:FN wells is because the cellbinding sites may already be occupied in the TNC220:FN binding complex.

When BSA blocking was performed after the two protein coats (both FN and TNC220 were bound to plastic and available for cell attachment) (experiment B), the addition of either anti-FN (HB5) or anti-TNC (HxB.9504) antibody decreased cell binding (Fig. 7). However, the greatest decrease in cell binding was found in the wells with both antibodies $(\mathrm{P}<0.05)$. These results indicate that both proteins are responsible for cell binding. Of note, the cell binding in the wells with both TNC220 and FN was increased compared to wells with $\mathrm{FN}$ alone $(\mathrm{P}=0.05)$, verifying the results shown in Figure 5.

\section{Discussion}

In this study we found that at maximal cell-binding concentrations, the small TNC isoform $(220 \mathrm{kDa})$ binds to $\mathrm{FN}$ whereas the large TNC isoform $(320 \mathrm{kDa})$ does not. Both proteins bind to plastic. However, the TNC220:FN complex is less adhesive for chondrosarcoma cells than is $\mathrm{FN}$ alone. If, however, the small TNC splice variant binds to plastic, it has additive adhesive properties with FN. The large TNC splice variant did not have adhesive properties in any of the assays performed. The cell-binding abilities of the TNC splice variants alone are significantly less than that of $\mathrm{FN}$ alone, implicating $\mathrm{FN}$ as a major adhesive molecule of the ECM.

Earlier studies in the literature reported that TNC inhibits cell attachment to FN (Chiquet-Ehrisman et al., 1988; Lightner, 1990; Lotz et al., 1989). One mechanism for the inhibition was steric blocking, in which the large hexabrachion covered up the adhesion sites on FN when it was able to bind to unblocked plastic (Joshi et al., 1993; Lightner, 1990). Other mechanisms involved possible interactions of specific tenascin segments with cell receptors (Lotz et al., 1989; Yokosaki, 1998). It is possible that the adhesive/antiadhesive role played by TNC is determined by its tissuespecific splicing pattern. The more recent elucidation of the various splice variants and techniques to reconstruct them have led to more detailed investigation of the adhesive/antiadhesive properties of the two major isoforms $(220 \mathrm{kDa}$ and $320 \mathrm{kDa}$ ) (Spring et al., 1989).

In support of our results, several investigators have found

\section{Experiment A: BSA between protein coats}

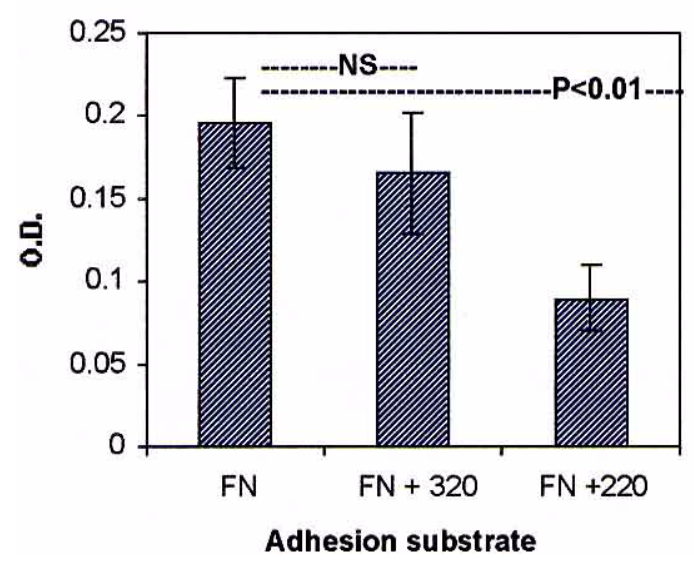

\section{Experiment B: BSA after both protein coats}

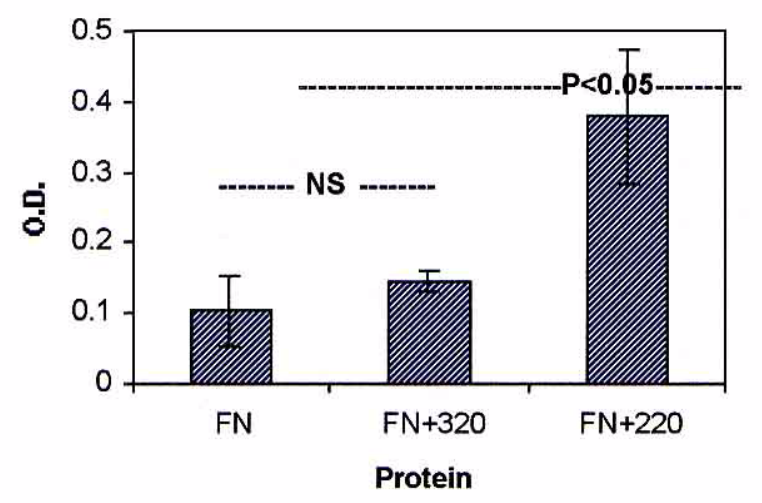

Fig. 5. Quantitation of $J J$ cell attachment to the protein-coated wells using a hexosaminidase substrate assay. At total of $100 \mu l$ of $J J$ cells at a concentration of $1 \times 10^{5} \mathrm{cell} / \mathrm{ml}$ were incubated in each well at $37^{\circ} \mathrm{C}$ for one hour. All experiments were performed in triplicate. The error bars represent standard deviation. Statistical analysis was performed with the use of the student's t-test analysis of variance. A P-value of $<0.05$ was considered statistically significant. In experiment A (left) in which the large TNC protein was not bound in the FN wells and the large TNC protein was bound to FN alone (and not to plastic), the TNC220:FN complex significantly inhibited cell attachment to FN (**P<0.01). The wells in which TNC 320 had been exposed to FN did not have a significant change in adhesion $(\mathrm{P}=0.15)$. In experiment $\mathrm{B}$ (right) in which both TNC wells contained $\mathrm{FN}$ and TNC bound to plastic, the large TNC splice variant had no effect on cell adhesion to $\mathrm{FN}(\mathrm{P}=0.15)$, whereas the small TNC protein significantly increased cell adhesion in the wells $(* \mathrm{P}<0.05)$. 


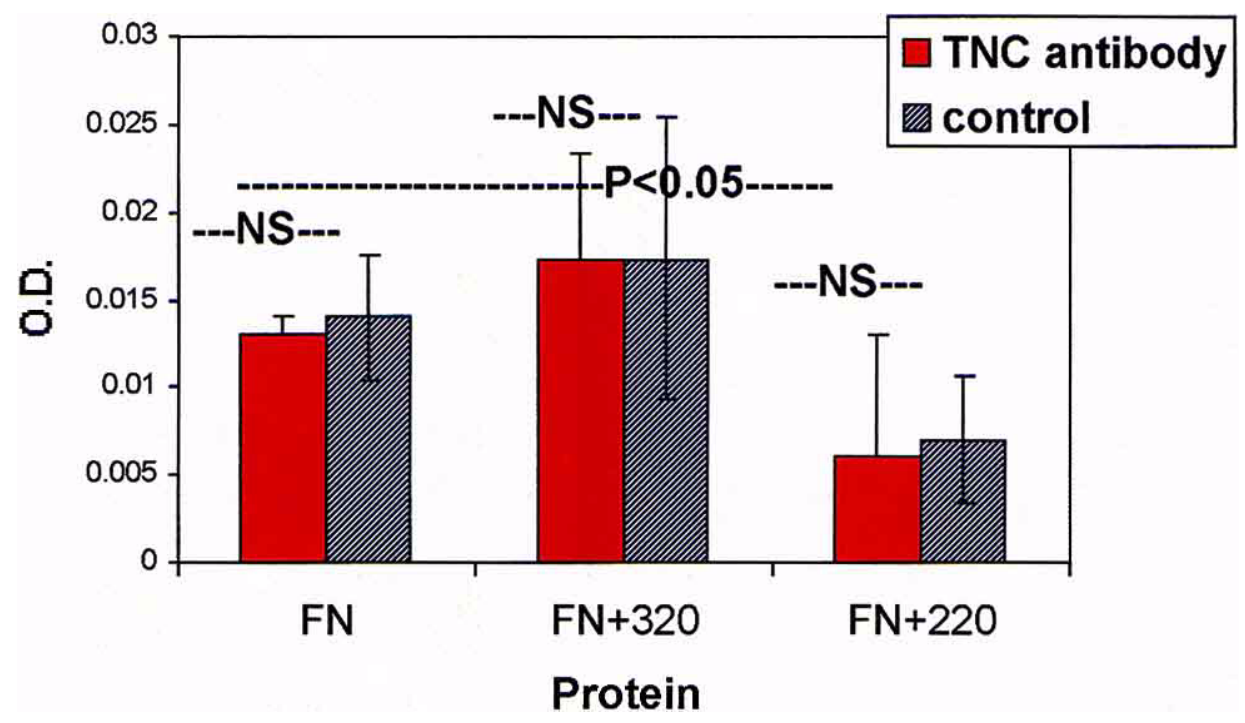

Fig. 6. Quantitation of $J J$ cell attachment to the protein-coated wells following antibody blocking with the polyclonal antibody HxB.9504 (anti-TNC terminal knob, identical for all TNC). Quantitation was performed using a hexosaminidase substrate assay. At total of $100 \mu 1$ of $J J$ cells at a concentration of $1 \times 10^{5} \mathrm{cell} / \mathrm{ml}$ were incubated in each well at $37^{\circ} \mathrm{C}$ for one hour following antibody blocking. All experiments were performed in triplicate. The error bars represent standard deviation. Statistical analysis was performed with the use of the student's t-test analysis of variance. A P-value of $<0.05$ was considered statistically significant. The TNC220:FN complex inhibited cell attachment to the protein-coated wells (*P<0.05). Antibody blocking of TNC did significantly affect binding in either the FN wells or the FN and TNC-coated wells.

that FN binds preferentially to the smaller TNC isoform. Chiqet-Ehrisman et al. used affinity chromatography and a solid-phase binding assay to study the interaction of FN with the two major chicken TNC isoforms (Chiquet-Ehrisman et al., 1991). The authors demonstrated that the small variant bound preferentially to fibronectin in enzyme-linked immunosorbent assay, and only the small variant was incorporated into the matrix by cultures of chicken fibroblasts. Chung et al studied human TNC, and confirmed that the small variant binds preferentially to purified fibronectin and to fibronectin-containing extracellular matrix (Chung et al., 1995). Using bacterial expression proteins, the authors mapped the major binding site to the third FN type III (FN3) region and to a minor binding site in the FN6-8 domain which is only positioned to bind fibronectin in the small splice variant.

Various other studies have verified that the small TNC isoform is concentrated in areas of cartilage deposition and matrix incorporation and have suggested that this phenomenon may be due to the small TNC protein interaction with FN (Chiquet-Ehrisman et al., 1991; Carnemolla et al., 1992; Chiquet-Ehrisman, 1993). The same investigators found that the larger TNC isoform does not accumulate at the site of synthesis but instead diffuses out of the matrix and accumulates in the media.

We found that the small TNC protein is adhesive for chondrosarcoma cells when bound to plastic in a mixture with FN. However, when bound to FN molecules, the TNC220:FN binding complex inhibited cell attachment. Although we are the first, to our knowledge to find that the small TNC splice variant alone has additive adhesive properties with FN, others have found that the TNC220:FN binding complex is anti-adhesive. Hauzenberger et al. used attachment assays, enzyme-linked immunoabsorbance assays and TNC molecules of various sizes to determine the effect of TNC on T- lymphocyte adhesion to fibronectin (Hauzenberger et al., 1999). The authors demonstrated that the TNC FN type III domains 1-5 bound to fibronectin and that the variable splicing region did not. In addition, the binding of the small TNC fragment inhibited antibody detection of the TNC binding site and inhibited T-lymphocyte attachment to FN. The authors concluded that the inhibition of cell attachment to FN involves the binding of TNC repeats TNfnIII 1-5 to FN.

Chung et al. likewise mapped the major FN binding site on TNC to the FNIII-3 domain and found that a monoclonal antibody against an epitope in this domain did not stain TNC segments bound to cell culture matrix fibrils (Chung et al., 1995). Fischer et al. used mutant TNC proteins to determine the cell-attachment roles of the various molecular domains (Fischer et al., 1997). The authors found that the fibrinogen knob was adhesive for cells. However, when TNC was added to the medium of fibroblasts plated on fibronectin-coated wells, cell adhesion was blocked by the interaction of the fibrinogen domain with FN. Similarly, Aukhil et al. mapped a cell-binding site on TNC to the fibrinogen domain. A growing body of literature therefore suggests that the small TNC isoform is able to bind FN at two possible binding sites, and that this binding blocks cell adhesion to both TNC 220 and FN. Conversely, the small 


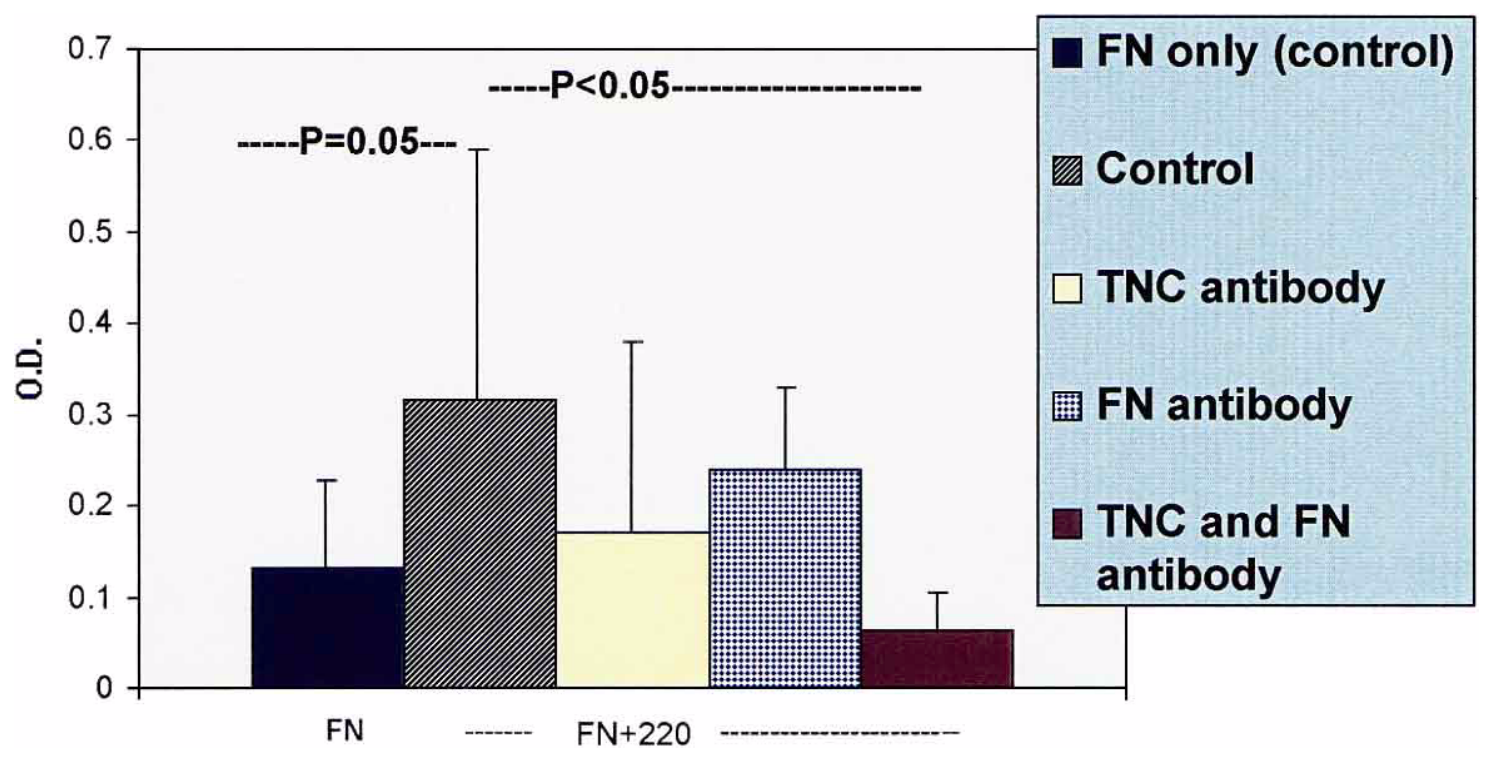

Fig. 7. Quantitation of $J J$ cell attachment to the wells coated with FN and TNC 220 (small) following antibody blocking with HxB.9504 (anti-TNC terminal knob, identical for all TNC), HB5 (anti-FN) or both. Quantitation was performed using a hexosaminidase substrate assay. At total of $100 \mu 1$ of $J J$ cells at a concentration of $1 \times 10^{5}$ cell $/ \mathrm{ml}$ were incubated in each well at $37^{\circ} \mathrm{C}$ for one hour following antibody blocking. All experiments were performed in triplicate. Statistical analysis was performed with the use of the student's t-test analysis of variance. A P-value of $<0.05$ was considered statistically significant. Error represent standard error for triplicate experiments. Antibody blocking of TNC and FN both decreased cell attachment to FN. However, the largest inhibition of cell attachment occurred in the wells blocked with both anti-TNC antibody and anti-FN antibody (*P<0.05). Of note, cell attachment was increased in the control wells with TNC220 and FN compared to the control wells with just FN alone (P=0.05).

TNC protein that is bound to plastic has both binding sites exposed and has adhesive properties for cells.

A finding in this study that contradicts previous investigations is that the large TNC splice variant, when bound to plastic, did not block cell adhesion to FN. These are in contrast to the findings of Lightner et al. who demonstrated that when bound to plastic, the large TNC molecule blocked cell adhesion to FN (Lightner, 1990). The authors suggested the possibility of a steric blocking mechanism for this observation. It is possible that the discrepancy in these results is related to the protein coat preparation. In the protocol published by Lightner et al., the protein coats were incubated at room temperature for 30 minutes. In our protocol, we incubated the protein overnight at $4^{\circ} \mathrm{C}$. We hypothesize that a conformational change occurs in the longer, colder incubation period in which the large TNC molecule loses its steric blocking three-dimensional structure. Another possible explanation for the discrepancy in results is the difference in cell lines studied with theoretically different matrix-binding properties. Further study is needed to clarify this phenomenon.

We have previously determined in our laboratory that normal human chondrocytes, when cultured in an alginate bead system, produce a large quantity of the small $220 \mathrm{kDa}$ TNC protein and incorporate it into the matrix ((Ghert et al., 2000), submitted for review). Chondrosarcoma cells have a distinctly different TNC splicing pattern than the chondrocytes in vitro. These cells produce predominantly the large
320-kDa-splice variant, which is not incorporated into the matrix but is diffused into the media. These latter results are supported in the literature for several other malignancies (Borsi et al., 1992; Carnemolla et al., 1992; Wilson et al., 1996). We have continued our investigation in order to clarify the role that the two major TNC isoforms play in the adhesive/anti-adhesive properties of the chondrosarcoma cell. We found that the $320-\mathrm{kDa}$ TNC protein does not bind to FN and does not promote cell adhesion. The $220 \mathrm{kDa}$ TN protein however, was found to bind to $\mathrm{FN}$ and to have both adhesive and anti-adhesive properties, depending on the substrate to which it is bound.

The metastatic cascade involves several steps including cell-matrix detachment, cell migration and invasion. The activity of the $320 \mathrm{kDa}$ TNC protein in tumor matrix is likely related to the induction of matrix degradation, invasion and cell migration (Jahkola et al., 1996, 1998; Shrestha et al., 1996; Tremble et al., 1994; Yoshida et al., 1999). These processes may involve functions other than cellmatrix anti-adhesion, namely the induction of proteolytic enzymes such as the metalloproteinases and basement membrane invasion. These other functions of TNC320 in malignant tissue would explain the lack of significant cellmatrix anti-adhesion found for TNC320 in this study. Further investigation into the possible roles for TNC320 in the process of metastasis is warranted.

The presence of the small TNC splice variant in the matrix of normal cartilage and the adhesive properties demon- 
strated in this study indicate a role for matrix-matrix and cell-matrix adhesion. The biologic activity of TNC in various tissues is therefore dependent on the tissue specific splicing patterns. The smaller TNC isoform likely plays a structural and adhesive role, whereas the larger isoform likely plays a role in tissue breakdown, cell migration and metastasis. Further elucidation of these specific roles has the potential to lead to novel therapeutic approaches to chondrosarcoma and other malignancies.

Acknowledgments. We thank Dr. Toomoo Ohashi, Dept. of Cell Biology, Duke University Medical Center, for the gift of the TNC 220 protein. This study was financially supported by the Orthopaedic Research and Education Foundation, the Musculoskeletal Transplant Foundation, The Piedmont Foundation and the National Institutes of Health Grant AR42863.

\section{References}

Angelov, D.N., Walther, M., Streppel, M., Guntinas-Lichius, O., Neiss, W. F., Probstmeier, R., and Pesheva, P. 1998. Tenascin-R is antiadhesive for activated microglia that induce downregulation of the protein after peripheral nerve injury: a new role in neuronal protection. J. Neurosci, 18: 6218-6229.

Aukhil, I., Joshi, P., Yan, Y., and Erickson, H.P. 1993. Cell- and heparinbinding domains of the hexabrachion arm identified by tenascin expression proteins. J. Biol. Chem., 268: 2542-2553.

Aukhil, I., Slemp, C.C., Lightner, V.A., Nishimura, K., Briscoe, G., and Erickson, H.P. 1990. Purification of hexabrachion (tenascin) from cell culture conditioned medium, and separation from a cell adhesion factor. Matrix, 10: 98-111.

Borsi, L., Carnemolla, B., Nicolo, G., Spina B., Tanare, G., and Zardi, L. 1992. Expression of different tenascin isoforms in normal, hyperplastic and neoplastic human breast tissues. Int. J. of Cancer, 52: 688-692.

Carnemolla, B., Borsi, L., Bannikov, G., Troyanovsky, S., and Zardi, L. 1992. Comparison of human tenascin expression in normal, simianvirus-40-transformed and tumor-derived cell lines. Eur. J. Biochem., 205: 561-567.

Chiquet-Ehrisman, R. 1993. Tenascin and other adhesion-modulating proteins in cancer. Cancer Biology, 4: 301-310.

Chiquet-Ehrisman, R., Kalla, P., Pearson, C.A., Beck, K., and Chiquet, M. 1988. Tenascin interferes with fibronectin action. Cell, 53: 383-390.

Chiquet-Ehrisman, R., Matsuoka, Y., Hofer, U., Spring, J., Bernasconi, C., and Chiqet, M. 1991. Tenascin variants: differential binding to fibronectin and distinct distribution in cell cultures and tissues. Cell Regulation., 2: 927-938.

Chung, C.Y., Murphy-Ullrich, J.E., and Erickson, H.P. 1996. Mitogenesis, cell migration, and loss of focal adhesions induced by tenascin-C interacting with its cell surface receptor, annexin II. Mol. Biol. Cell, 7: 883892.

Chung, C.Y., Zardi, L., and Erickson, H.P. 1995. Binding of tenascin-C to soluble fibronectin and matrix fibrils. J. Biol. Chem., 270: 29012-29017.

Dalkowski, A., Schuppan, D., Orfanos, C.E., and Zouboulis, C.C. 1999. Increased expression of tenascin $\mathrm{C}$ by keloids in vivo and in vitro. $B r . J$. Dermatol., 141: 50-56.

Elefteriou, F., Exposito, J.Y., Garrone, R., and Lethias, C. 1999. Cell adhesion to tenascin-X mapping of cell adhesion sites and identification of integrin receptors. Eur. J. Biochem., 263: 840-848.

Erickson, H. and Bourdon, M.A. 1989. Tenascin: an extracellular matrix protein promiment in specialized embryonic tissues and tumors. Аппи. Rev. Cell Biol., 5: 71-92.

Fischer, D., Brown-Ludi, M., Schulthess, T., and Chiquet-Ehrismann, R.
1997. Concerted action of tenascin-C domains in cell adhesion, anti-adhesion and promotion of neurite outgrowth. J. Cell. Sci., 110: 15131522.

Fischer, D., Tucker, R.P., Chiquet-Ehrismann, R., and Adams, J.C. 1997. Cell-adhesive responses to tenascin-C splice variants involve formation of fascin microspikes. Mol. Biol. Cell., 8: 2055-2075.

Gassler, N., Rastar, F., and Hentz, M.W. 1999. Angiogenesis and expression of tenascin after transmural laser revascularization. Histol. Histopathol., 14: 81-87.

Ghert, M.A., Erickson, H.P., Block, J.A., Jung, S.T., and scull, S.P. 2000. Tenascin-c expression and distribution in cultured human chondrocytes and chondrosarcoma cells. submitted to J. Ortho. Res., in press.

Gluhak, J., Mais, A., and Mina, M. 1996. Tenascin-C is associated with early stages of chondrogenesis by chick mandibular ectomesenchymal cells in vivo and in vitro. Dev. Dyn., 205: 24-40.

Goussia, A.C., Ioachim, E.E., Peschos, D., Assimakopoulos, D.A., Skevas, A., and Agnantis, N.J. 2000. Expression of the extracellular matrix protein tenascin in laryngeal epithelial lesions: correlation with fibronectin, CD44, cathepsin D and proliferation indices. Virchows. Arch., 436: 579584.

Hakkinen, L., Hildebrand, H.C., Berndt, A., Kosmehl, H., and Larjava, H. 2000. Immunolocalization of tenascin- $\mathrm{C}$, alpha9 integrin subunit, and alphavbeta6 integrin during wound healing in human oral mucosa. $J$. Histochem. Cytochem., 48: 985-998.

Hauzenberger, D., Olivier, P., Gundersen, D., and Ruegg, C. 1999. Tenascin-C inhibits beta1 integrin-dependent $\mathrm{T}$ lymphocyte adhesion to fibronectin through the binding of its fnIII 1-5 repeats to fibronectin. Eur. J. Immunol., 29: 1435-1447.

Husmann, K., Carbonetto, S., and Schachner, M. 1995. Distinct sites on tenascin-C mediate repellent or adhesive interactions with different neuronal cell types. Cell. Adhes. Commun., 3: 293-310.

Jahkola, T., Toivonen, T., Nordling, S., von Smitten, K., and Virtanen, I. 1998. Expression of tenascin-C in intraductal carcinoma of human breast: relationship to invasion. Eur. J. Cancer, 34: 1687-1692.

Jahkola, T., Toivonen, T., Virtanen, I., von Smitten, K., Nordling, S., von Boguslawski, K., Haglund, C., Nevanlinna, H., and Blomqvist, C. 1998. Tenascin-C expression in invasion border of early breast cancer: a predictor of local and distant recurrence. Br. J. Cancer, 78: 1507-1513.

Jahkola, T., Toivonen, T., von Smitten, K., Blomqvist, C., and Virtanen, I. 1996. Expression of tenascin in invasion border of early breast cancer correlates with higher risk of distant metastasis. Int. J. Cancer, 69: 445447.

Jallo, G.I., Friedlander, D.R., Kelly, P.J., Wisoff, J.H., Grumet, M., and Zagzag, D. 1997. Tenascin-C expression in the cyst wall and fluid of human brain tumors correlates with angiogenesis. Neurosurgery, 41: 1052-1059.

Jones, F.S. and Jones, P.L. 2000. The tenascin family of ECM glycoproteins: structure, function, and regulation during embryonic development and tissue remodeling. Dev. Dyn., 218: 235-259.

Joshi, P., Chung, C.Y., Aukhil, I., and Erickson, H.P. 1993. Endothelial cells adhere to the RGD domain and the fibrinogen-like terminal knob of tenascin. J. Cell Sci., 106: 389-400.

Kafitz, K.W. and Greer, C.A. 1998. Differential expression of extracellular matrix and cell adhesion molecules in the olfactory nerve and glomerular layers of adult rats [published erratum appears in J. Neurobiol., 35: 118]. J. Neurobiol., 34: 271-282.

Kalembey, I., Yoshida, T., Iriyama, K., and Sakakura, T. 1997. Analysis of tenascin mRNA expression in the murine mammary gland from embryogenesis to carcinogenesis: an in situ hybridization study. Int. $J$. Dev. Biol., 41: 569-573.

Kiernan, B.W., Gotz, B., Faissner, A., and Ffrench-Constant, C. 1996. Tenascin-C inhibits oligodendrocyte precursor cell migration by both adhesion-dependent and adhesion-independent mechanisms. Mol. Cell. 
Neurosci., 7: 322-335.

Klein-Soyer, C., Ceraline, J., Orvain, C., de la Salle, C., Bergerat, J.P., and Cazenave, J.P. 1997. Angiogenesis inhibitor SR 25989 upregulates thrombospondin-1 expression in human vascular endothelial cells and foreskin fibroblasts. Biol. Cell., 89: 295-307.

Kostianovsky, M., Greco, M.A., Cangiarella, J., and Zagzag, D. 1997. Tenascin-C expression in ultrastructurally defined angiogenic and vasculogenic lesions. Ultrastruct. Pathol., 21: 537-544.

Kurpad, S.N., Zhao, X.G., Wikstrand, C.J., Batra, S.K., McLendon, R.E., and Bigner, D.D. 1995. Tumor antigens in astrocytic gliomas. Glia, 15: 244-256.

Landegren, U. 1984. Measurement of cell numbers by means of the endogenous enzyme hexosaminidase. Applications to detections of lymphokines and cell surface antigens. J. Immunol. Methods, 67: 379388.

Latijnhouwers, M.A., Bergers, M., Van Bergen, B.H., Spruijt, K.I., Andriessen, M.P., and Schalkwijk, J. 1996. Tenascin expression during wound healing in human skin. J. Pathol., 178: 30-35.

Lightner, V.A. and Erickson, H.P. 1990. Binding of hexabrachion (tenascin) to the extracellular matrix and substratum and its effect on cell adhesion. J. Cell Sci., 95: 263-277.

Ljubimov, A.V., Saghizadeh, M., Spirin, K.S., Khin, H.L., Lewin, S.L., Zardi, L., Bourdon, M.A., and Kenney, M.C. 1998. Expression of tenascin-C splice variants in normal and bullous keratopathy human corneas. Invest. Ophthalmol. Vis. Sci., 39: 1135-1142.

Lotz, M.M., Burdsal, C.A., Erickson H.P., and McClay, D.R. 1989. Cell adhesion to fibronection and tenascin: Quantitative measurements of initial binding and subsequent stregthening response. J. Cell Biol., 109: 1795-1805.

Mackie, E.J. and Murphy, L.I. 1998. The role of tenascin-C and related glycoproteins in early chondrogenesis. Microsc. Res. Tech., 43: 102110.

Mackie, E.J. and Ramsey, S. 1996. Expression of tenascin in joint-associated tissues during development and postnatal growth. J. Anat., 188: 157-165.

Nicolo, M., Piccolino, F.C., Zardi, L., Giovannini, A., and Mariotti, C. 2000. Detection of tenascin-C in surgically excised choroidal neovascular membranes. Graefes Arch. Clin. Exp. Ophthalmol., 238: 107111.

Pacifici, M. 1995. Tenascin-C and the development of articular cartilage. Matrix Biol., 14: 689-698.

Ribatti, D., Loverro, G., Vacca, A., Greco, P., Roncali, L., and Selvaggi, L. 1998. Expression of tenascin is related to angiogenesis in pre- eclampsia. Eur. J. Clin. Invest., 28: 373-378.

Riedl, S., Kadmon, M., Tandara, A., Hinz, U., Moller, P., and Faissner, A. 1997. Tenascin-C tissue concentration in inflammatory and neoplastic diseases of the colon mucosa. Anticancer Res., 17: 3165-3166.

Savarese, J.J., Erickson, H., and Scully, S.P. 1996. Articular chondrocyte tenascin-C production and assembly into de novo extracellular matrix. $J$. Orthop. Res., 14: 273-281.

Shrestha, P., Sumitomo, S., Lee, C.H., Nagahara, K., Kamegai, A., Yamanaka, T., Takeuchi, H., Kusakabe, M., and Mori, M. 1996. Tenascin: growth and adhesion modulation--extracellular matrix degrading function: an in vitro study. Eur. J. Cancer B. Oral. Oncol., 32B: $106-113$.

Spring, J., Beck, K., and Chiquet-Ehrismann, R. 1989. Two contrary functions of tenascin: Dissection of the active sites by recombinant tenascin fragments. Cell, 59: 325-334.

Tremble, P., Ruth Chiquet-Ehrismann, R. and Werb, Z. 1994. The extracellular matrix ligands fibronectin and tenascin collaborate in regulating collagenase gene expression in fibroblasts. Mol. Biol. Cell, 5: 439-453.

Vacca, A., Ribatti, D., Fanelli, M., Costantino, F., Nico, B., Di Stefano, R., Serio, G., and Dammacco, F. 1996. Expression of tenascin is related to histologic malignancy and angiogenesis in b-cell non-Hodgkin's lymphomas. Leuk Lymphoma, 22: 473-481.

Vollmer, G. 1997. Biologic and oncologic implications of tenascin-C/ hexabrachion proteins. Crit. Rev. Oncol. Hematol., 25: 187-210.

Wilson, K.E., Bartlett, J.M., Miller, E.P., Smyth, J.F., Mullen, P., Miller, W.R., and Langdon, S.P. 1999. Regulation and function of the extracellular matrix protein tenascin-C in ovarian cancer cell lines. $B r . J$. Cancer, 80: 685-692.

Wilson, K.E., Langdon, S.P., Lessells, A.M., and Miller, W.R. 1996. Expression of the extracellular matrix protein tenascin in malignant and benign ovarian tumours. Br. J. Cancer, 74: 999-1004.

Yokosaki, Y., Matsuura, N., Higashiyama, S., Murakami, I., Obara, M., Yamakido, M., Shigeto, N., Chen, J., and Sheppard, D. 1998. Identification of the ligand binding site for the integrin alpha9 beta1 in the third fibronectin type III repeat of tenascin-C. J. Biol Chem., 273: 1142311428 .

Yoshida, T., Yoshimura, E., Numata, H., Sakakura, Y., and Sakakura, T. 1999. Involvement of tenascin-C in proliferation and migration of laryngeal carcinoma cells. Virchows. Arch., 435: 496-500.

(Received for publication, November 20, 2001

and in revised form, April 9, 2001) 